\title{
Structure and Bonding in a Bis(silazane) Ruthenium Complex. Catalytic Selective Deuteration of Disilazane
}

Tahra Ayed, ${ }^{\dagger,+}$ Jean Claude Barthelat,${ }^{\dagger}$ Bahoueddine Tangour, ${ }^{\dagger}$ Caroline Pradère, ${ }^{\perp}$ Bruno Donnadieu, ${ }^{\perp, \S}$ Mary Grellier ${ }^{\perp} *$ and Sylviane Sabo-Etienne ${ }^{\perp}, *$

Laboratoire de Physique Quantique, IRSAMC (UMR 5626), Université Paul Sabatier, 118 route de Narbonne, 31062 Toulouse Cedex 4, France.

I.P.E.I. El Manar, Université de Tunis-El Manar, Tunisia.

Laboratoire de Chimie de Coordination du CNRS, 205 route de Narbonne, 31077 Toulouse Cedex 04, France.

grellie@1cc-toulouse.fr ; sabo@1cc-toulouse.fr

\section{Supporting Information file}

\section{$\underline{\text { Contents: }}$}

- Synthesis and characterization of compound 2.

- Computational details.

- $\quad$ X-ray data for compound 2. These data are given as CIF files. 


\section{Experimental details}

All reactions and workup procedures were performed under an argon atmosphere using conventional vacuum line and Schlenk tube techniques. Solvents were dried and freshly distilled according to standard procedures and degassed prior to use. $\mathrm{RuH}_{2}\left(\mathrm{H}_{2}\right)_{2}\left(\mathrm{PCy}_{3}\right)_{2}(\mathbf{1})$ was prepared according to a published procedure. ${ }^{1} \mathrm{NMR}$ solvents were dried and degassed using appropriated methods. NMR spectra were acquired on Brucker AC 200, DPX 300 and AMX 400 spectrometers. Microanalysis were performed by the Laboratoire de Chimie de Coordination Microanalytical Service. Infrared spectra were obtained as Nujol mulls on a Perkin-Elmer 1725 FT-IR spectrometer.

Synthesis of $\left[\mathrm{RuH}_{2}\left\{\left(\eta^{2}-\mathrm{HSiR}_{2}\right)_{2} \mathrm{NH}\right\}\left(\mathrm{PCy}_{3}\right)_{2}\right](\mathbf{2})$.

$\left(\mathrm{Me}_{2} \mathrm{SiH}\right)_{2} \mathrm{NH}(65 \mu \mathrm{L}, 0.37 \mathrm{mmol})$ was added at room temperature to a suspension of $\mathbf{1}$ (122 $\mathrm{mg}, 0.18 \mathrm{mmol})$ in pentane $(8 \mathrm{~mL})$. Vigorous stirring was maintained for 30 min during which time the mixture turned orange with formation of a white precipitate (after $2 \mathrm{~min}$ ). The solid was collected by filtration, washed twice with pentane $(2 \mathrm{~mL})$, and dried under argon and finally under vacuum.Yield, 72\%. A similar procedure was employed for crystallization except that the stirring bar was removed as soon as the mixture became homogeneous. The solution was then kept at room temperature for a slow crystallization occuring within $1 \mathrm{~h}$. The solution was removed and the colorless crystals were collected.

${ }^{1} \mathrm{H}$ NMR (400.13 MHz, C $\left.7 \mathrm{D}_{8}, 298 \mathrm{~K}\right) \delta=2.2-1.2\left(4\right.$ broad m, $\left.66 \mathrm{H}, 2 \mathrm{PCy}_{3}\right), 0.86(\mathrm{~s}, 12 \mathrm{H}, 4$ Me), -9.80 (br s, $4 \mathrm{H}, \mathrm{Ru}-H) .{ }^{31} \mathrm{P}\left\{{ }^{1} \mathrm{H}\right\} \mathrm{NMR}\left(161.98 \mathrm{MHz}, \mathrm{C}_{7} \mathrm{D}_{8}, 298 \mathrm{~K}\right) \delta=53.5$ (s). IR $\left(\mathrm{cm}^{-1}\right) v(\mathrm{~N}-\mathrm{H}) 3390(\mathrm{~s}) ; \mathrm{v}(\mathrm{Ru}-\mathrm{H}) 2040$ (s), 1972; v(Si-H) 1712 (s).

Anal. Calcd. for $\mathrm{C}_{40} \mathrm{H}_{83} \mathrm{NP}_{2} \mathrm{RuSi}_{2} \mathrm{C}, 60.26 ; \mathrm{H}, 10.49 ; \mathrm{N}, 1.76 \%$. Found: C, 60.09; H, 10.24; $\mathrm{N}, 1.56 \%$. 


\section{Computational details}

DFT calculations were performed with the GAUSSIAN 98 series of programs ${ }^{2}$ using two nonlocal hybrid functionals denoted as B3LYP ${ }^{3}$ and B3PW91 ${ }^{4}$. For ruthenium, the core electrons were represented by a relativistic small-core pseudopotential using the DurandBarthelat method. ${ }^{5}$ The 16 electrons corresponding to the $4 \mathrm{~s}, 4 \mathrm{p}, 4 \mathrm{~d}$ and $5 \mathrm{~s}$ atomic orbitals were described by a (7s, 6p, 6d) primitive set of Gaussian functions contracted to (5s, 5p, 3d). Standard pseudopotentials developed in Toulouse were used to describe the atomic cores of all other non-hydrogen atoms $(\mathrm{C}, \mathrm{N}, \mathrm{Si}$ and $\mathrm{P}) .{ }^{6}$ A double plus polarization valence basis set was employed for N, Si and P (d-type function exponents were 0.95, 0.45 and 0.45, respectively). For hydrogen, a standard primitive (4s) basis contracted to $(2 \mathrm{~s})$ was used. A p type polarization function (exponent 0.9 ) was added for the hydrogen atoms directly bound to ruthenium. The geometry of the various critical points on the potential energy surface was fully optimized with the gradient method available in GAUSSIAN 98. Calculations of harmonic vibrational frequencies were performed to determine the nature of each critical point.

(1) Borowski, A. F.; Sabo-Etienne, S.; Christ, M. L.; Donnadieu, B.; Chaudret, B. Organometallics 1996, 15, 1427.

(2) Frisch, M. J.; Trucks, G. W.; Schlegel, H. B.; Scuseria, G. E.; Robb, M. A.; Cheeseman, J. R.; Zakrzewski, V. G.; Montgomery, J. A., Jr.; Stratmann, R. E.; Burant, J. C.; Dapprich, S.; Millam, J. M.; Daniels, A. D.; Kudin, K. N.; Strain, M. C.; Farkas, O.; Tomasi, J.; Barone, V.; Cossi, M.; Cammi, R.; Mennucci, B.; Pomelli, C.; Adamo, C.; Clifford, S.; Ochterski, J.; Petersson, G. A.; Ayala, P. Y.; Cui, Q.; Morokuma, K.; Salvador, P.; Dannenberg, J. J.; Malick, D. K.; Rabuck, A. D.; Raghavachari, K.; Foresman, J. B.; Cioslowski, J.; Ortiz, J. V.; Baboul, A. G.; Stefanov, B. B.; Liu, G.; Liashenko, A.; Piskorz, P.; Komaromi, I.; Gomperts, R.; Martin, R. L.; Fox, D. J.; Keith, T.; Al-Laham, M. A.; Peng, C. Y.; Nanayakkara, A.; Challacombe, M.; Gill, P. M. W.; Johnson, B.; Chen, W.; Wong, M. W.; Andres, J. L.; Gonzalez, C.; Head-Gordon, M.; Replogle, E. S.; Pople, J. A.Gaussian 98, Revision A.11; Gaussian, Inc.; Pittsburgh, PA, 2001. 
(3) (a) Becke, A. D. J. Chem. Phys. 1993, 98, 5648. (b) Lee, C.; Yang, W.; Parr R.G. Phys. Rev. B. 1988, 37, 785.

(4) Perdew, J. P.; Wang, Y. Phys. Rev. B. 1992, 45, 13244.

(5) Durand, P.; Barthelat, J.-C. Theor. Chim. Acta 1975, 38, 283.

(6) Bouteiller, Y.; Mijoule, C.; Nizam, M.; Barthelat, J.-C.; Daudey, J.-P.; Pélissier, M.; Silvi, B. Mol. Phys. 1988, 65, 2664. 